\title{
FAKTOR-FAKTOR YANG MEMPENGARUHI KEBERHASILAN USAHA PEDAGANG PASAR SUKARAMAI DI KECAMATAN BENGKALIS
}

\author{
Mashuri, Eriyana, Ezril \\ Sekolah Tinggi Ilmu Ekonomi (STIE) Syariah Bengkalis \\ Email: mashurymr@gmail.com, eryanarina@yahoo.com, ezrilnur@gmail.com
}

\begin{abstract}
ABSTRAK
Penelitian ini bertujuan untuk mengetahui pengaruh modal, jumlah tenaga kerja, tingkat pendidikan, pengalaman, lama jam kerja, usia para pedagang pasar terhadap tingkat keberhasilan usaha para pedagang di pasar Sukaramai kecamatan Bengkalis. Penelitian ini merupakan penelitian inferensial dengan pendekatan kuantitatif. Teknik pengambilan sampel menggunakan simple random sampling jumlah yang digunakan sebagai sampel sebanyak 47 orang pemilik toko (kios). Teknik pengumpulan data primer menggunakan kuesioner, wawancara serta observasi lapangan. Metode analisis yang digunakan adalah analisis regresi linier berganda. Hasil penelitian ini menunjukan bahwa terdapat pengaruh positif modal terhadap pendapatan pedagang di pasar Sukaramai Bengkalis yang ditunjukan dengan nilai koefisien standar regresi sebesar 0,673. Terdapat pengaruh tenaga kerja dengan nilai koefisien standar regresi sebesar 0,295, tidak terdapat pengaruh pendidikan (dummy variable) dan lama usaha (pengalaman) terhadap peningkatan pendapatan (keberhasilan usaha), terdapat pengaruh positif lama jam kerja dengan nilai koefisien standar regresi sebesar 0,229, dan tidak terdapat pengaruh usia terhadap keberhasilan para pedagang di pasar Sukaramai kecamatan Bengkalis. Sedangkan secara simultan yakni pengaruh modal, jumlah tenaga kerja, tingkat pendidikan, pengalaman, lama jam kerja, usia terhadap tingkat keberhasilan pedagang di pasar Sukaramai kecamatan Bengkalis sebesar 94,8\% sedangkan sisanya sebesar 5,2\% dijelaskan oleh variabel lain yang tidak diteliti dalam penelitian ini.
\end{abstract}

Kata Kunci: Usaha, Faktor Keberhasilan.

\section{PENDAHULUAN}

Keberhasilan dan kegagalan dalam dunia usaha secara substansi merupakan dua hal yang berbeda. Secara sederhana ukuran keberhasilan usaha dari sudut pandang ekonomi dapat dilihat dari keadaan finansial atas usaha yang dijalankan. Jika usaha yang dijalankan dapat memberi kelabihan masukan atas pengeluaran yang dilakukan maka ini dapat dikatakan usaha tersebut memungkinkan untuk diteruskan. Dan sebaliknya jika usaha yang dilakukan kelebihan pengeluaran daripada masukan hal ini dapat dikatakan usaha tersebut tidak layak untuk dilanjutkan. Keberhasilan dan kesuksesan suatu usaha selalu diraih dengan usaha yang gigih. Keberhasilan hari ini harus dipertahankan untuk hari esok dan seterusnya.

Terdapat banyak faktor yang mempengaruhi kesuksesan atau keberhasilan usaha yang dijalankan oleh usahawan. Menurut (Purnama dan Suyatno 2010) 
faktor penentu keberhasilan usaha industri kecil, berdasarkan hasil penelitiannya menemukan bahwa keberhasilan usaha kecil ditandai oleh inovasi, perilaku mau mengambil resiko. Begitu juga hasil penelitian Murphy dalam sumber yang sama menemukan bahwa keberhasilan usaha kecil disumbangkan oleh kerja keras, dedikasi, dan komitmen terhadap pelayanan dan kualitas.

Menurut (Tambunan 2002) faktor-faktor yang mampengaruhi keberhasilan usaha diantaranya yaitu : kualitas sdm, penguasaan organisasi, struktur organisasi, sistem manajemen, partisipasi, kultur/budaya bisnis, kekuatan modal, jaringan bisnis dengan pihak luar, dan tingkat entrepreneurship. Menurut (Glancey dalam Priyanto 2009) Wirausaha yang memiliki kemampuan mengambil keputusan yang superior akan dapat meningkatkan performansi usaha seperti peningkatan profit dan petumbuhan usaha. Dan masih menurut menurut (Priyanto 2009), seseorang yang memiliki kewirausahaan tinggi dan digabung dengan kemampuan manajerial yang memadai akan menyebabkan dia sukses dalam usahanya. (Erliah 2007): Suatu usaha dikatakan berhasil di dalam usahanya apabila setelah jangka waktu tertentu usaha tersebut mengalami peningkatan baik dalam permodalan, skala usaha, hasil atau laba, jenis usaha atau pengelolaan" . Menurut (Primiana 2009): "Keberhasilan usaha adalah permodalan sudah terpenuhi, penyaluran yang produktif dan tercapainya tujuan organisasi”. Dari pernyataan diatas dapat dikatakan bahwa keberhasilan suatu usaha dipengaruhi oleh banyak faktor. Untuk dapat mengetahui faktor-faktor mana yang dominan terhadap keberhasilan suatu usaha perlu dilakukan kajian. Oleh demikian peneliti akan mengadakan penelitian tentang "Faktor-faktor yang mempengaruhi keberhasilan usaha pedagang pasar Sukaramai di kecamatan Bengkalis".

Berdasarkan latar belakang masalah diatas dapat diketahui bahwa terdapat berbagai faktor yang dapat mempengaruhi keberhasilan suatu usaha dalam melakukan bisnis. Untuk mengetahui faktor-faktor yang mempengaruhi keberhasilan suatu usaha, maka dalam penelitian ini dapat dirumuskan sebagai berikut:

1. Faktor-faktor apa yang dapat mempengaruhi keberhasilan usaha pedagang pasar tradisional di kecamatan Bengkalis.

2. Faktor-faktor mana yang lebih dominan dalam mempengaruhi keberhasilan usaha pedagang pasar tradisional di kecamatan Bengkalis.

Berdasarkan rumusan masalah diatas tentang berbagai faktor yang dapat mempengaruhi keberhasilan usaha bagi pedagang pasar, maka dalam penelitian ini bertujuan untuk:

1. Untuk menganalisis faktor-faktor apa yang dapat mempengaruhi keberhasilan usaha pedagang pasar tradisional di kecamatan Bengkalis.

2. Untuk menganalisis faktor-faktor yang lebih dominan dalam mempengaruhi keberhasilan usaha pedagang pasar tradisional di kecamatan Bengkalis.

Definisi operasional variabel dalam penelitian ini sebagai berikut:

1. Modal (X1) merupakan sebagai investasi untuk menjalankan kegiatan usaha. Secara logis dapat dikemukakan bahwa semakin tinggi modal kerja yang dikeluarkan oleh pedagang maka semakin tinggi pula laba bersih yang dihasilkan (ceteris paribus dengan asumsi semua barang dapat terjual).

2. Jumlah tenaga kerja (X2) adalah banyaknya orang yang melakukan pekerjaan pada usaha tersebut. 
3. Tingkat pendidikan (X3) adalah pendidikan terakhir yang ditempuh oleh pemilik usaha. Dalam penelitian ini pendidikan sebagai variabel dummy.

4. Pengalaman (X4) adalah lama waktu pemilik usaha sudah menjalankan usahanya.

5. Lama jam kerja (X5) adalah lamanya jam usaha dalam beroperasi.

6. Usia (X6) adalah usia pedagang pasar sukaramai pada saat dilakukan penelitian diukur dengan satuan tahun.

7. Tingkat keberhasilan usaha (Y): adalah besarnya rata-rata laba yang diperoleh setiap hari dengan satuan rupiah.

Berdasarkan kerangka pemikiran pada gambar diatas maka dapat dijadikan pedoman untuk diajukan hipotesis penelitian sebagai berikut:

1. H1: terdapat hubungan signifikan antara variabel modal terhadap tingkat keberhasilan usaha pedagang pasar

2. H2: terdapat hubungan signifikan antara jumlah tenaga kerja terhadap tingkat keberhasilan usaha

3. H3: terdapat hubungan signifikan antara variabel tingkat pendidikan terhadap tingkat keberhasilan usaha

4. H4: terdapat hubungan signifikan antara variabel pengalaman terhadap tingkat keberhasilan usaha

5. H5: terdapat hubungan signifikan antara variabel lama jam kerja terhadap tingkat keberhasilan usaha

6. H6: terdapat hubungan signifikan antara variabel Usia pedagang terhadap tingkat keberhasilan usaha

7. H7: terdapat hubungan signifikan secara simultan antara variabel modal, jumlah tenaga kerja, tingkat pendidikan, pengalaman, lama jam kerja, usia para pedagang pasar terhadap tingkat keberhasilan usaha

\section{TINJAUAN PUSTAKA}

\section{Keberhasilan Usaha}

Setiap jenis usaha tentu saja berkeinginan untuk mencapai suatu titik yang disebut keberhasilan. Keberhasilan suatu usaha dapat diukur melalui pengukuran kinerja yang dapat dilihat dari berbagai aspek, seperti kinerja keuangan dan image perusahaan. Menurut (Primiana 2009, 49) mengemukakan bahwa keberhasilan usaha adalah permodalan sudah terpenuhi, penyaluran yang produktif dan tercapainya tujuan organisasi. Sedangkan menurut (Algifari 2003, 118) ia berpendapat bahwa keberhasilan usaha dapat dilihat dari efisiensi proses produksi yang dikelompokkan berdasarkan efisiensi secara ekonomis.

Menurut (Purnama 2010, 179) berkaitan dengan faktor penentu keberhasilan usaha industri kecil ini, hasil penelitiannya menemukan bahwa keberhasilan usaha kecil ditandai oleh inovasi, perilaku mau mengambil resiko. Begitu juga hasil penelitian Murphy dalam sumber yang sama menemukan bahwa keberhasilan usaha kecil disumbangkan oleh kerja keras, dedikasi, dan komitmen terhadap pelayanan dan kualitas. Berbagai faktor penentu keberhasilan usaha industri kecil hasil identifikasi penelitian Luch tersebut pada dasarnya adalah cerminan dari kemampuan usaha (pengetahuan, sikap dan keterampilan), pengalaman yang relevan, motivasi kerja dan tingkat pendidikan seseorang pengusaha. Sehingga dapat diketahui bahwa keberhasilan usaha dapat dipengaruhi 
oleh kemampuan usaha yang tercermin diantarannya melalui pengetahuan, sikap, dan keterampilan dari pengusaha.

Dalam islam, bisnis atau dagang tidak hanya diarahkan pada mencari untung (keberhasilan dan kesuksesan) yang sebesar-besarnya dan menghalalkan segala cara. Menurut (Hendra dan Riana 2008, 164) ada empat prinsip yang dipegang oleh Rasul ketika berbisnis, yaitu shiddiq (jujur), amanah (menepati janji), fathanah (mempunyai wawasan yang luas), dan tabligh (berkomunikasi). Keempat hal inilah yang membuat beliau sukses dalam menjalankan bisnisnya. Sedangkan menurut (Dawwabah 2014, 29-54) prinsip-prinsip keimanan entrepreneur muslim diantaranya, yaitu; 1) Meyakini bahwa harta milik Allah;2) Manusia hanya diberi mandat; 3) Menghadirkan niat yang baik dalam bekerja; 4) Mengimani qadha dan takdir Allah; 5) Disertai sikap selalu bersyukur; 6) Siap menjalani proses dan bekerja untuk mendapatkan rezeki; 7) Meyakini bahwa Allah telah menentukan kelebihan atas orang lain.

Berdasarkan prinsip-prinsip dagang diatas dapat disimpulkan bahwa dalam islam, keberhasilan dan kesuksesan suatu usaha tidak terlepas dari keberkahan harta dan cara meraihnya. Motivasi berdagang dalam islam juga untuk membantu masyarakat menyediakan barang kebutuhannya dan keuntungan yang diharapkan bukan hanya di dunia, tetapi juga di akhirat. Sedangkan Nabi Muhammad SAW mengikuti prinsip-prinsip perdagangan yang adil dalam transaksinya. Selain itu Rasul juga selalu menasehati para sahabatnya untuk melakukan hal serupa.

Maksud prinsip-prinsip dagang dalam tulisan ini adalah bahwa ketika berdagang seorang pedagang haruslah memiliki rambu-rambu berdagang. Dan seorang entrepreneur atau pedagang melaksanakan rambu-rambu perdagangan sesuai dengan syari'at Islam. Hal tersebut dilakukan demi kelancaran dagangnya, karena keberhasilan usaha dagang semata-mata untuk mendapatkan ridho dari Allah SWT.

\section{Faktor-Faktor Keberhasilan Usaha}

\section{Modal Usaha}

Menurut Kamus Besar Bahasa Indonesia "modal usaha adalah uang yang dipakai sebagai pokok (induk) untuk berdagang, melepas uang, dan sebagainya; harta benda (uang, barang, dan sebagainya) yang dapat dipergunakan untuk menghasilkan sesuatu yang menambah kekayaan". Modal dalam pengertian ini dapat diinterpretasikan sebagai sejumlah uang yang digunakan dalam menjalankan kegiatan-kegiatan bisnis. Banyak kalangan yang memandang bahwa modal uang bukanlah segala-galanya dalam sebuah bisnis. Namun perlu dipahami bahwa uang dalam sebuah usaha sangat diperlukan. Persoalan di sini bukanlah penting tidaknya modal, karena keberadaannya memang sangat diperlukan, akan tetapi bagaimana mengelola modal secara optimal sehingga bisnis yang dijalankan dapat berjalan lancar (Amirullah 2009, 7).

Modal dalam konsep ekonomi Islam berarti semua harta yang bernilai dalam pandangan syar'i, dimana aktivitas manusia ikut berperan serta dalam usaha produksinya dengan tujuan pengembangan. Uang merupakan modal serta salah satu faktor produksi yang penting, tetapi bukan yang terpenting karena manusia menduduki tempat di atas modal yang disusul oleh sumber daya alam. Pandangan ini berbeda dengan pandangan sementara pelaku ekonomi modern 
yang memandang uang segala sesuatu, sehingga tidak jarang manusia atau sumber daya alam dianiaya atau ditelantarkan.

Modal dalam sistem ekonomi Islam diharuskan terus berkembang agar sirkulasi uang tidak berhenti. Dikarenakan jika uang atau modal terhenti maka harta itu tidak akan mendatangkan manfaat bagi orang lain, namun seandainya jika uang diinvestasikan dan digunakan untuk melakukan bisnis maka uang tersebut akan mendatangkan manfaat bagi orang lain, termasuk diantaranya jika ada bisnis yang berjalan maka akan bisa menyerap tenaga kerja. Sebagaimana Allah SWT. berfirman dalam QS. Al-Baqarah: 279 yang berbunyi sebagai berikut:

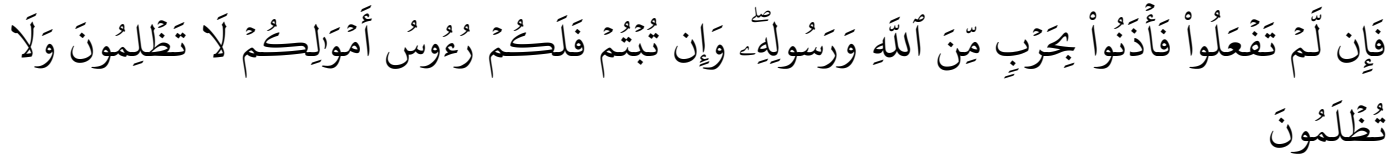

Artinya: Maka jika kamu tidak mengerjakan (meninggalkan sisa riba), Maka ketahuilah, bahwa Allah dan Rasul-Nya akan memerangimu. dan jika kamu bertaubat (dari pengambilan riba), Maka bagimu pokok hartamu; kamu tidak Menganiaya dan tidak (pula) dianiaya.

Ayat ini menjelaskan bahwa meneruskan hidup dengan riba setelah menjadi orang Islam, berarti memaklumkan perang kepada Allah SWT. dan Rasul. Dengan ancaman yang keras itu, dapatlah dipahamkan bahwasanya seluruh harta yang diperibakan itu, atau bunganya dari harta itu, semuanya menjadi harta yang haram kelanjutannya ialah bahwa daulah islamiyah berhak merampas seluruh harta itu, baik modal pokok, maupun bunganya. Tetapi kalau kamu telah taubat tidak hendak melanjutkan lagi kehidupan yang jahat itu, maka harta yang kamu pinjamkan sebanyak jumlah asalnya, bolehlah kamu ambil kembali.

\section{Tenaga Kerja}

Tenaga Kerja merupakan faktor yang penting dalam kegiatan produksi, karena pekerja inilah yang mengalokasikan dan memanfaatkan faktor - faktor lain guna menghasilkan suatu output yang bermanfaat. Tenaga kerja adalah setiap orang yang mampu melakukan pekerjaan baik di dalam maupun di luar hubungan kerja guna menghasilkan barang atau jasa guna memenuhi kebutuhan masyarakat.

Syari'at Islam juga membahas dan memperhatikan kehidupan manusia dalam kapasitasnya sebagai "pekerja" dan tentunya memuat prinsip-prinsip dan aturan serta konsepsi tentang "kerja" dan ajaran untuk selalu "bekerja". Pemanfaatan tenaga kerja manusia dalam rangka mengejawantahkan dan mengaktualisasikan fungsi kekhalifaan dan sekaligus fungsinya sebagai pembangun, sangat dihargai oleh ajaran (syari'at Islam). Sehubungan dengan hal tersebut, manusia sebagai pekerja, mutlak memperhatikan kemungkinankemungkinan yang dapat dipergunakan sebagai bahan pertimbangan melaksanakan aktivitasnya.

\section{Pendidikan}

Menurut (Kamus besar Bahasa Indonesia 2002, 232) "pendidikan adalah proses perubahan sikap dan tingkah laku seseorang atau kelompok orang dalam usaha mendewasakan manusia melalui upaya pengajaran dan pelatihan". Dapat disimpulkan Pendidikan merupakan suatu usaha yang dilakukan secara sadar guna mengembangkan pengetahuan dan ketrampilan melalui usaha belajar. Semakin 
tinggi tingkat pendidikan seseorang, maka semakin tinggi pula keahlian atau ketrampilan seseorang. Bila dilihat dari produktivitas kerja, pendidikan dan pendapatan seseorang mempunyai hubungan yang sangat erat.

Dalam pendidikan terdapat jenis dan jenjang pendidikan. Menurut (Wikipedia Bahasa Indonesia 2011), jenis pendidikan dibagi menjadi tiga yaitu: pendidikan formal, pendidikan informal dan pendidikan non formal, Jenjang pendidikan merupakan pengertian tahapan pendidikan berkelanjuatan yang ditetapkan berdasar tingkat perkembangan peserta didik, keluasan dan kedalaman bahan pengajaran dan cara penyajian. Menurut UU RI No.20/2003, mengenai jenjang pendidikan dijelaskan: "jenjang pendidikan yang termasuk jalur pendidikan sekolah terdiri atas pendidikan dasar, pendidikan menengah dan pendidikan tinggi'.

Menurut (Simanjuntak 2001) pendidikan menberikan pengetahuan bukan saja yang langsung dengan pelaksanaan tugas, akan tetapi juga landasan untuk memperkembangkan diri serta kemampuan memanfaatkan semua sarana yang ada di sekitar kita untuk kelancaran pelaksanaan tugas.

\section{Pengalaman}

Lamanya seorang pelaku bisnis menekuni bidang usaha akan mempengaruhi kemampuan profesionalnya. Semakin lama menekuni bidang usaha perdagangan akan makin meningkatkan pengalaman (pengetahuan) tentang selera ataupun perilaku konsumen. Ketrampilan berdagang makin bertambah dan semakin banyak pula relasi bisnis maupun pelanggan yang berhasil dijaring (Asmie 2008).

\section{Lama Jam Kerja}

Jam kerja adalah waktu untuk melakukan pekerjaan, dapat dilaksanakan siang hari dan/atau malam hari (UURI No.13 Tahun 2003 tentang Tenaga Kerja). Badan Pusat Statistik mendefinisikan Jumlah jam kerja seluruh pekerjaan adalah lamanya waktu dalam jam yang digunakan untuk bekerja dari seluruh pekerjaan, tidak termasuk jam kerja istirahat resmi dan jam kerja yang digunakan untuk halhal di luar pekerjaan selama seminggu yang lalu. Bagi pedagang keliling, jumlah jam kerja dihitung mulai berangkat dari rumah sampai tiba kembali di rumah dikurangi waktu yang tidak merupakan jam kerja, seperti mampir ke rumah famili/kawan dan sebagainya.

Menurut (Mc.Eachern (2001) waktu adalah bahan mentah dari hidup. Dalam menggunakan waktu ada tiga cara: a) Melaksanakan pekerjaan pasar yaitu menjual waktu ke pasar untuk memperoleh pendapatan; b) Melaksanakan pekerjaan non-pasar yaitu menggunakan waktu untuk memproduksi barang dan jasa sendiri; c) Mengubah waktu langsung menjadi waktu luang (leisure), yaitu penggunaan waktu untuk non-kerja.

(Arifin 2004, 15 dalam Sasmita 2012, 3) dalam bukunya yang berjudul Formasi Strategi Makro-Mikro Ekonomi Indonesia mengemukakan secara umum dapat diasumsikan bahwa "semakin banyak jam kerja yang dipergunakan, berarti akan semakin produktif”. Mengindikasikan semakin tinggi jam kerja yang di jalani pedagang maka semakin tinggi pendapatan yang diperoleh. Hal ini dapat disimpulkan bahwa hubungan jam kerja terhadap pendapatan bersifat positif. 


\section{Usia}

Usia adalah seseorang masih mampu bekerja dan menghasilkan sesuatu. Menurut (Simanjuntak 2001), umur mempunyai hubungan terhadap responsibilitas seseorang akan penawaran tenaga kerjanya. Semakin tinggi tingkat umur, semakin kecil proporsi penduduk yang bersekolah sehingga tingkat partisipasi kerja pada kelompok umur dewasa lebih besar daripada TPK pada kelompok umur yag lebih muda. Semakin meningkat umur seseorang semakin besar penawaran tenaga kerjanya. Sedangkan selama masih dalam usia produktif, semakin tua usia seseorang semakin besar tanggung jawabnya terhadap keluarga yang harus ditanggung. Menurut (Hasyim 2006), umur dapat dijadikan sebagai tolok ukur dalam melihat aktivitas seseorang dalam bekerja, dimana kondisi umur yang masih produktif, maka kemungkinan besar seseorang dapat bekerja dengan baik dan maksimal.

\section{METODOLOGI PENELITIAN}

\section{Analisis Deskriptif}

Analisis deskriptif digunakan untuk menganalisis data dengan cara mendeskripsikan atau menggambarkan data yang telah terkumpul sebagaimana adanya tanpa bermaksud membuat kesimpulan yang bermaksud untuk umum atau generalisasi (Sugiyono 2015). Dalam statistik deskriptif diantaranya terdapat nilai rata-rata (mean), nilai maksimum, median, dan modus. Mean diperoleh dari jumlah total dibagi jumlah individu. Median adalah suatu nilai yang membatasi $50 \%$ dari frekuensi distribusi setelah bawah. Modus adalah nilai variabel yang mempunyai frekuensi terbanyak dalam distribusi. Selain itu, data juga berbentuk tabel distribusi frekuensi.

\section{Uji Prasyarat Analisis}

Uji prasyarat analisis atau yang biasa disebut uji asumsi klasik dilakukan dalam penelitian ini bertujuan untuk menguji data-data yang digunakan dalam penelitian ini apakah telah memenuhi syarat asumsi klasik.

\section{a. Uji Normalitas}

Uji normalitas digunakan untuk menguji apakah data yang bersangkutan berdistribusi normal atau tidak. Uji normalitas dapat dilakukan dengan menggunakan uji Kolmogorov-Smirnov. Dimana data dapat dikatakan berdistribusi normal jika nilai Asymp. Sig (2 tailed) $\geq 0,05$ maka data berdistribusi normal, jika nilai Asymp. Sig (2 tailed) $<0,05$ maka data berdistribusi tidak normal (Muhson 2012).

\section{b. Uji Multikolinearitas}

Uji multikolinearitas digunakan untuk melihat ada tidaknya hubungan yang sangat kuat atau sempurna antar variabel bebas (X). Untuk menguji ada tidaknya multikolinearitas antar variabel bebas $(\mathrm{X})$ maka dapat menggunakan uji VIF (Variance Inflation Factor). Jika nilai VIF kurang dari 4 maka tidak terjadi multikolinearitas, sedangkan jika nilai VIF lebih dari 4 maka terjadi mutikolinearitas, (Muhson 2012). 


\section{Uji Hipotesis}

a. Mencari Persamaan Garis Regresi Enam Prediktor Setelah uji asumsi klasik dilakukan, langkah selanjutnya adalah melakukan analisis regresi. Menurut Sugiyono (2015) analisis regresi ganda digunakan oleh peneliti, bila peneliti bermaksud meramalkan bagaimana keadaan (naik turunnya) variabel dependen (kriterium), bila dua atau lebih variabel independen sebagai faktor prediktor dimanipulasi (dinaik turunkan nilainya). Jadi analisis ganda akan dilakukan bila jumlah variabel independennya minimal.

$b$. Persamaan regresi yang digunakan adalah persamaan regresi linear berganda (multi regression).

Model persamaan regresi yang disusun pada penelitian ini:

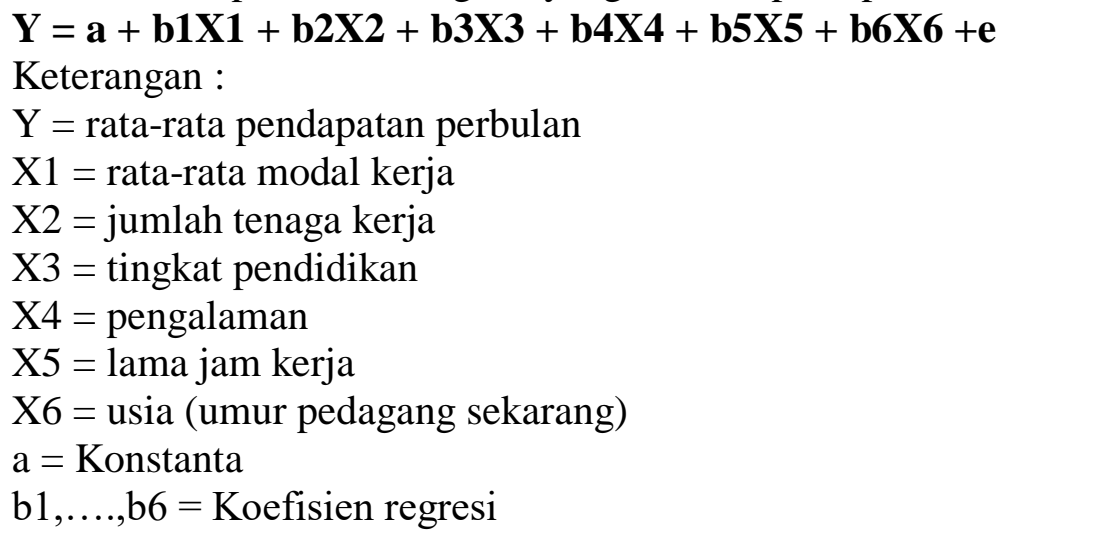

\section{Uji Simultan (Uji F)}

Menurut (Ghozali 2011) Uji F digunakan untuk mengetahui apakah semua variabel bebas secara bersama-sama (simultan) dapat berpengaruh terhadap variabel terikat. Uji $\mathrm{F}$ digunakan untuk menghitung besarnya perubahan nilai variabel terikat yang dapat dijelaskan oleh perubahan nilai semua variabel bebas. Pengujian ini dilakukan dengan melihat nilai signifikansi pada Fhitung jika nilai sig $\leq 0,05$ maka Ho ditolak, artinya variabel bebas berpengaruh signiifikan terhadap variabel terikat, sedangkan jika nilai sig > 0,05 maka Ho diterima, artinya variabel bebas tidak berpengaruh signifikan terhadap variabel terikat. Dengan perumusan hipotesis :

Ho : tidak ada pengaruh antara variabel modal, tenaga kerja, pengalaman, umur, lama jam kerja, pendidikan secara bersama-sama terhadap keberhasilan (pendapatan) pedagang pasar Sukaramai Kecamatan Bengkalis.

$\mathrm{Ha}$ : ada pengaruh antara variabel modal, tenaga kerja, pengalaman, umur, lama jam kerja, pendidikan secara bersama-sama terhadap keberhasilan (pendapatan) pedagang pasar Sukaramai kecamatan Bengkalis.

\section{Analisis Koefisien Determinan (R2)}

Koefisien determinasi pada intinya mengukur seberapa jauh kemampuan model dalam menerangkan variasi variabel terikat. Nilai koefisien determinasi adalah antara nol dan satu $\left(0 \leq \mathrm{R}^{2} \geq 1\right)$. Nilai $\mathrm{R}^{2}$ yang kecil berarti kemampuan variabel bebas dalam menjelaskan variabel terikat sangat terbatas. Nilai yang mendekati satu berarti variabel bebas memberikan hampir semua informasi yang dibutuhkan untuk memprediksi variasi variabel terikat secara simultan (Sugiyono 2015). 


\section{HASIL DAN PEMBAHASAN}

\section{Profil Responden}

a. Pendidikan

Dalam pelaksanaan pendidikan telah dibentuk suatu sistem pengajaran nasional yang merupakan realisasi UUD 1945 pasal 31 yang menyatakan bahwa: "tiap-tiap warga Negara berhak mendapatkan pengajaran." Pendidikan melalui dua jalur, yaitu pendidikan sekolah atau pendidikan formal dan pendidikan luar sekolah atau non formal, baik negeri maupun swasta. Berdasarkan wawancara penulis dengan pemilik toko Pasar Sukaramai kecamatan Bengkalis, bahwa masyarakat pedagang Pasar Sukaramai kecamatan Bengkalis umumnya mempunyai pendidikan SLTA ke bawah. Untuk lebih jelas dapat dilihat pada tabel 1 di bawah ini:

Tabel 1

Pendidikan

\begin{tabular}{lrrrr}
\hline $\begin{array}{l}\text { Tingkat } \\
\text { Pendidikan }\end{array}$ & $\begin{array}{c}\text { Frequenc } \\
\mathrm{y}\end{array}$ & Percent & $\begin{array}{c}\text { Valid } \\
\text { Percent }\end{array}$ & $\begin{array}{r}\text { Cumulative } \\
\text { Percent }\end{array}$ \\
\hline SLTP & 14 & 29,8 & 29,8 & 29,8 \\
SLTA & 28 & 59,6 & 59,6 & 89,4 \\
SARJANA & 5 & 10,6 & 10,6 & 100,0 \\
Total & 47 & 100,0 & 100,0 & \\
\hline \hline
\end{tabular}

Sumber : Data primer diolah SPSS 22

Berdasarkan dari tabel 1 di atas menunjukkan bahwa sebagian besar responden banyak tamatan SLTA yakni sebanyak 59\% atau 28 orang, dan tamatan SLTP sebanyak 14 orang atau 29\% sedangkan yang menempuh perguruan tinggi sebanya $10 \%$ atau 5 orang. Dan tidak ditemukan bagi responden yang tidak berpendidikan.

b. Gender (Jenis Kelamin)

Gender atau jenis kelamin para pedagang pasar menentukan keberhasilan usaha yang digelutinya. Berdasarkan sebaran angket tentang jenis kelamin para pedagang pasar sukaramai kecamatan bengkalis dapat dilihat pada tabel 2 dibawah ini :

Tabel 2

Gender

\begin{tabular}{lrrrrr}
\hline & Frequency & Percent & Valid Percent & & Cumulative Percent \\
\cline { 2 - 4 } Laki-laki & 20 & 42,6 & 42,6 & 42,6 \\
Perempuan & 27 & 57,4 & 57,4 & 100,0 \\
Total & 47 & 100,0 & 100,0 & \\
\hline \hline
\end{tabular}

Sumber : Data primer diolah SPSS 22

Berdasarkan data pada tabel 2 di atas, dapat dikatakan bahwa pedagang pasar Sukaramai kecamatan Bengkalis lebih banyak berjenis kelamin perempuan dari pada laki-laki. Berdasarkan hasil tabulasi kuesioner yang dilakukan 
dilapangan bahwa pedagang yang berjenis kelamin perempuan sebanyak $57,4 \%$ atau sebanyak 27 orang, dan pedagang yang berjenis kelamin laki-laki sebanyak $42,6 \%$ atau sebanyak 20 orang. Wawancara yang dilakukan kepada pemilik toko (kios) yang ada di lokasi penelitian mengatakan bahwa laki-laki yang sudag beristri lebih memilih bekerja ditempat lain agar mendapat tambahan pendapatan karena modal dan tokonya kecil. Agama yang dianut para pedagang sukarmai kecamatan bengkalis Pada dasarnya Islam tidak melarang ummatnya untuk melakukan usaha perdagangan, asalkan perdagangan itu tidak menyalahi ketentuan-ketentuan yang telah di tetapkan oleh Islam.

Berdasarkan hasil kuesioner yang dilakukan dilokasi penelitian didapati bahwa seluruh pedagang di Pasar Sukaramai kecamatan Bengkalis adalah beragama Islam. Berdasarkan hasil observasi juga didapati bahwa masyarakat atau para pedagang pasar sukaramai bengkalis tergolong fanatik dalam menjalankan ibadah. Ini dapat dilihat ketika waktu shalat tiba, sebagian besar para pedagang menunaikan ibadah dimasjid terdekat baik pemilik toko ataupun antara sesama karyawan secara bergantian. Maka dengan kondisi yang demikian dapat dikatakan kehidupan beragama bagi pedagang Pasar Sukaramai Kecamatan Bengkalis dipandang sangat penting sebagai asas pembentukan mental dan moral dalam melaksanakan aktifitas perdagangannya untuk memenuhi kebutuhan diri maupun keluarga.

\section{Uji Normalitas}

Uji normalitas digunakan untuk menguji apakah data yang bersangkutan berdistribusi normal atau tidak. Uji normalitas dapat dilakukan dengan menggunakan uji Kolmogorov-Smirnov. Dimana data dapat dikatakan berdistribusi normal jika nilai Asymp. Sig (2-tailed) $\geq 0,05$ maka data berdistribusi normal, jika nilai Asymp. Sig (2-tailed) $<0,05$ maka data berdistribusi tidak normal, (Muhson 2012). Berikut ini disajikan data hasil dari pengujian normalitas sebagai berikut:

Tabel 3

One-Sample Kolmogorov-Smirnov Test

\begin{tabular}{llr}
\hline & & Unstandardized Residual \\
\hline $\mathrm{N}$ & & 47 \\
Normal Parameters & Std. &, 0649 \\
& Deviation &, 111 \\
& Absolute &, 088 \\
Most Extreme Differences & Positive &,- 111 \\
& Negative &, 761 \\
Kolmogorov-Smirnov Z & &, 609 \\
Asymp. Sig. (2-tailed) & & \\
\hline \hline Sumber: Data primer diolah SPSS 20 & &
\end{tabular}

Berdasarkan tabel 3 di atas diketahui nilai dari Asymp. Sig (2-tailed) pada nilai Residual variabel modal, tenaga kerja, pendidian, lama usaha, lama jam kerja, umur, dan pendapatan menunjukkan nilai Asymp. Sig. (2-tailed) 0,609 > 0.05 yang berarti semua data berdistribusi normal. 


\section{Uji Linearitas}

Uji linearitas dimaksudkan untuk mengetahui apakah antara variabel bebas dan variabel terikat mempunyai hubungan linear atau tidak. Untuk mengetahui hal ini digunakan uji $\mathrm{F}$ pada taraf signifikansi 5\%. Jika nilai Sig $\mathrm{F}<0,05$ maka hubungannya tidak linear, sedangkan jika nilai Sig $\mathrm{F} \geq 0,05$ maka hubungannya bersifat linear, (Muhson 2012).

\section{Tabel 4}

\section{Uji Linearitas}

\begin{tabular}{llll}
\hline Variabel & F (deviation from linearity) & Sig. & Ket \\
\hline Modal (X1) & 0,639 & 0,845 & Linear \\
Tenaga Kerja (X2) & 1,250 & 0,297 & Linear \\
Pendidikan (X3) & 3,028 & 0,059 & Linear \\
Lama Usaha (X4) & 0,993 & 0,489 & Linear \\
Lama Jam Kerja (X5) & 2,051 & 0,074 & Linear \\
Usia (X6) & 1,032 & 0,462 & Linear \\
\hline \hline
\end{tabular}

Sumber : Data primer diolah SPSS 20

Berdasarkan pada tabel 4 di atas diketahui nilai Sig variabel bebas yang terdiri dari modal, tenaga kerja, pendidikan, lama usaha, lama jam kerja, dan usia terhadap pendapatan nilai Sig. > 0,05 maka hubungan antar variabel tersebut dapat dikatakan linear.

\section{Uji Multikoleniaritas}

Uji multikolinearitas bertujuan untuk menguji apakah model regresi yang ditemukan adanya korelasi antar variabel bebas. Model regresi yang baik seharusnya tidak terjadi korelasi diantara variabel bebas. Jika variabel bebas saling berkorelasi maka variabel ini tidak ortogonal. Variabel ortogonal adalah variabel bebas yang nilai korelasi antar variabel bebas sama dengan nol. Multikolinearitas dapat dilihat dari tolerance dan lawannya VIF (Variance Inflation Factor), jika nilai tolerance > 0,10 dan VIF kurang dari 10 maka tidak terjadi multikolineartias, Imam Ghozali (2005). Berikut disajikan hasil dari pengujian multikolinearitas sebagai berikut:

Tabel 5

\section{Coefficients Multikoleniaritas}

\begin{tabular}{lccc}
\hline & \multicolumn{2}{c}{ Collinearity } & \\
Variabel & Statistics & Keterangan \\
& Toleranc & VIF & \\
\hline Modal (X1) &, 164 & 6,101 & Tidak terjadi multikolinearitas \\
Tenaga kerja &, 191 & 5,246 & Tidak terjadi multikolinearitas \\
(X2) &, 319 & 3,138 & Tidak terjadi multikolinearitas \\
Pendidikan (X3) &, 260 & 3,851 & Tidak terjadi multikolinearitas \\
Lama usaha (X4) &, 212 & 4,718 & Tidak terjadi multikolinearitas \\
Lama jam krj &, 708 & 1,413 & Tidak terjadi multikolinearitas \\
(X5) & & \\
Usia (X6) &
\end{tabular}


Berdasarkan tabel 5 di atas maka dapat disimpulkan bahwa antara variabel modal, tenaga kerja, pendidikan, lama usaha, lama jam kerja, dan umur tidak saling mempengaruhi atau tidak terjadi multikolinearitas.

\section{Analisis Regresi}

Tabel 6

Output Analisis Regresi

\begin{tabular}{lccc}
\hline & Koefisien unstandar & $\begin{array}{c}\text { Koefisien } \\
\text { standar }\end{array}$ & Sig. \\
\hline Konstanta &, 547 & &, 395 \\
Modal (X1) &, 565 &, 673 &, 000 \\
Tenaga kerja (X2) &, 403 &, 295 &, 001 \\
Pendidikan (X3) &,- 223 &,- 116 &, 120 \\
Lama usaha (X4) &,- 125 &,- 099 &, 259 \\
Lama jam kerja &, 703 &, 229 &, 005 \\
(X5) &, 321 &, 075 &, 097 \\
Usia (X6) & & &
\end{tabular}

Berdasarkan nilai standardized coefficients (koefisien standar) dapat diketahui bahwa variabel independen yang memiliki pengaruh paling kuat terhadap perolehan pendapatan (keberhasilan usaha) adalah modal kerja (X1). Hal ini ditunjukkan dari nilainya yang paling tinggi, yaitu sebesar 0,637. Urutan variabel berikutnya dari pengaruh yang paling kuat sampai yang paling lemah adalah jumlah tenaga kerja (X2), jumlah jam kerja (X5), usia (X6), tingkat pendidikan (X3), dan paling lemah adalah pengalaman atau lama usaha (X4).

Persamaan hasil regresi bebagai berikut:

$\log \mathrm{Y}=0,547+0,673 \log \mathrm{X} 1+0,295 \log \mathrm{X} 2-0,116 \log \mathrm{X} 3-0,099 \log \mathrm{X} 4+0$, $229 \log \mathrm{X} 5+0,075 \log \mathrm{X} 6$

$\mathrm{a}=\operatorname{antilog} 0,547=3,523$

Persamaan regresi menjadi:

$\mathrm{Y}=3,523+\mathrm{X} 1^{0,673}+\mathrm{X} 2^{0,295}-\mathrm{X} 3^{0,116}-\mathrm{X} 4^{0,099}+\mathrm{X} 5^{0,229}+\mathrm{X} 6^{0,075}$

\section{Uji Hipotesis}

a. Pengujian hipotesis $\mathrm{H} 1$

Berdasarkan tabel 6 diketahui nilai probabilitas signifikansi variabel modal kerja (X1) sebesar 0,000. Nilai probabilitas signifikansi $<0,05$ maka Ho ditolak. Dengan demikian dapat disimpulkan bahwa modal kerja berpengaruh signifikan terhadap tingkat keberhasilan usaha pedagang pasar suka ramai di Kecamatan Bengkalis. Dengan demikian dapat dikatakan bahwa semakin tinggi modal kerja maka semakin tinggi pula pendapatan yang diperoleh pedagang pasar suka ramai dengan asumsi variabel lain bersifat konstan (ceteris paribus). Penambahan jumlah modal kerja secara signifikan akan meningkatkan laba.

b. Pengujian hipotesis $\mathrm{H} 2$

Berdasarkan tabel 6 diketahui nilai probabilitas signifikansi variabel Jumlah tenaga kerja (X2) sebesar 0,001. Nilai probabilitas signifikansi > 0,05 maka 
Ho ditolak. Dengan demikian dapat disimpulkan bahwa jumlah tenaga kerja berpengaruh terhadap tingkat keberhasilan usaha pada pedagang Sukaramai kecamatan Bengkalis. Jumlah tenaga kerja berpengaruh signifikan terhadap tingkat keberhasilan usaha. Semakin banyak jumlah tenaga kerja maka semakin tinggi pula laba yang diperoleh oleh pedagang dengan asumsi variabel lain bersifat konstan (ceteris paribus). Berdasarkan hasil wawancara informal, dapat diketahui bahwa penjual akan menambah jumlah tenaga kerja baru apabila kondisi usahanya memiliki kecenderungan trend penjualannya meningkat. Hasil penelitian (Purba 1990) perlu diperhatikan, yang mengemukakan bahwa penambahan jumlah tenaga kerja akan berpengaruh negatif terhadap produktivitas tenaga kerja. Apabila dikaitkan dengan kondisi usaha dagang dipasar sukaramai kecamatan bengkalis, penambahan jumlah tenaga kerja pada tingkat tertentu akan meningkatkan pendapatan tapi jika ditambah terus maka akan menurunkan pendapatan.

c. Pengujian hipotesis $\mathrm{H} 3$

Berdasarkan tabel 6 diketahui nilai probabilitas signifikansi variabel tingkat pendidikan (X3) sebesar 0,120. Nilai probabilitas signifikansi > 0,05 maka Ho diterima. Dengan demikian dapat disimpulkan bahwa tingkat pendidikan tidak berpengaruh terhadap tingkat keberhasilan usaha dagang di pasar Sukaramai kecamatan Bengkalis. Tingkat pendidikan tidak berpengaruh signifikan terhadap tingkat keberhasilan usaha dagang. Semakin tinggi tingkat pendidikan maka semakin tinggi pula laba bersih yang diperoleh para pedagang dengan asumsi variabel lain bersifat konstan (ceteris paribus). Dalam penelitian ini, penjual yang memiliki pendidikan lebih tinggi secara rata-rata tidak memiliki perbedaan perolehan pendapatan dibandingkan dengan penjual yang memiliki tingkat pendidikan yang lebih rendah. Persaingan usaha di pasar sukaramai yang berada dipusat kota kecamatan bengkalis bersifat persaingan sempurna. Setiap orang dapat dengan mudah untuk menjalankan usahanya karena tidak membutuhkan modal yang besar, keahlian atau kualifikasi khusus maupun persyaratan tingkat pendidikan tertentu. pedagang yang memiliki tingkat pendidikan tinggi memang memperoleh laba bersih yang lebih tinggi, namun perolehan laba antara penjual yang berpendidikan sarjana, SMU, SLTP dan SD tidak ada perbedaan. Hasil penelitian ini memperkuat penelitian terdahulu (Ellyyawati dan Susilo 2001) bahwa pendidikan tidak mempengaruhi tingkat keberhasilan usaha yang dicapai, mereka yang memiliki pendidikan rendah mampu mencapai tingkat keberhasilan yang tinggi. Atau dengan kata lain, tingkat keberhasilan usaha seseorang pada bidang usaha kecil tidak ditentukan dari tingkat pendidikannya.

\section{d. Pengujian hipotesis $\mathrm{H} 4$}

Berdasarkan tabel 6 diketahui nilai probabilitas signifikansi variabel lama usaha (X4) sebesar 0,259. Nilai probabilitas signifikansi > 0,05 maka Ho diterima. Dengan demikian dapat disimpulkan bahwa lama usaha atau pengalaman bekerja tidak berpengaruh signifikan terhadap tingkat keberhasilan usaha dagang di pasar Sukaramai kecamatan Bengkalis. Lama usaha tidak berpengaruh signifikan terhadap tingkat keberhasilan usaha dagang. Semakin banyak/lama usaha yang dijalankan pedagang pasar sukaramai maka semakin tinggi pendapatan yang diperoleh penjual pasar 
sukaramai dengan asumsi variabel lain bersifat konstan (ceteris paribus). Penjual yang memiliki pengalaman kerja yang lebih lama, perolehan laba bersihnya memang relatif lebih tinggi, namun selisihnya tidak berbeda secara signifikan dibandingkan dengan penjual yang pengalamannya lebih sedikit variabel pengalaman kerja tidak berpengaruh karena usaha dagang yang bersifat tunggu bola. Sebagian besar penjual cenderung pasif dan tidak melakukan suatu strategi tertentu untuk menarik pembeli, hanya ada beberapa penjual yang melakukan strategi-strategi khusus untuk menarik pembeli. Misalnya menyediakan fasilitas televisi, ruang dingin, kursi santai diskon harga dan sebagainya. Pada usaha tertentu ada yang membutuhkan pengalaman untuk memulai meningkatkan hasil penjualannyamisalnya usaha tekstik, usaha keramik, dan usaha mebel (Marniyati 2002), maka pengalaman usaha sangat diperlukan.

e. Pengujian hipotesis $\mathrm{H} 5$

Berdasarkan tabel 6 diketahui nilai probabilitas signifikansi variabel lama jam kerja (X5) sebesar 0,005. Nilai probabilitas signifikansi $<0,05$ maka Ho ditolak. Dengan demikian dapat disimpulkan bahwa lama jam kerja berpengaruh signifikan terhadap tingkat keberhasilan usaha pada usaha dagang pasar Sukaramai di kecamatan Bengkalis. Jumlah jam kerja berpengaruh signifikan terhadap tingkat keberhasilan usaha artinya semakin lama jam kerja maka semakin tinggi pula tingkat keberhasilan usaha dagang yang diperoleh dengan asumsi variabel lain bersifat konstan (ceteris paribus). Penambahan jumlah jam kerja secara signifikan akan meningkatkan laba bersih.

f. Pengujian hipotesis H6

Berdasarkan tabel 6 diketahui nilai probabilitas signifikansi variabel usia (X6) sebesar 0,097. Nilai probabilitas signifikansi > 0,05 maka Ho diterima. Dapat disimpulkan bahwa faktor usia dalam meningkatkan pendapatan usaha dagang dipasar Sukaramai tidak berpengaruh signifikan terhadap tingkat keberhasilan usaha dagang tersebut. Tua atau muda usia para pedagang pasar sukaramai tidak berpengaruh terhadap peningkatan pendapatan. Artinya tidak ada perbedaan pendapatan baik pedagang tersebut lebih muda atau lebih tua. Jadi pedagang pasar di usia yang produktif maupun tidak tetap berdagang dengan baik, hal ini terlihat dari hasil penelitian ini. Pedagang di usia yang sudah tua tetap berdagang dengan baik karena faktor kebutuhan selain itu karena pengalaman berdagang lebih lama dari pada yang usia muda. Sedangkan pada usia muda pedagang tetap berdagang secara produktif karena memiliki tenaga yang kuat hanya saja pengalaman yang didapatkan lebih banyak yang usia tua. Sehingga dalam penelitian ini variabel usia tidak memberikan pengaruh terhadap pendapatan pedagang di pasar Sukaramai kecamatan Bengkalis.

\section{Uji Silmutan (Uji F)}

Uji $\mathrm{F}$ digunakan untuk menghitung besarnya perubahan nilai variabel terikat yang dapat dijelaskan oleh perubahan nilai semua variabel bebas. Pengujian ini dilakukan dengan melihat nilai signifikansi pada $\mathrm{F}$ hitung atau signifikansi. jika $\mathrm{F}$ hitung $>\mathrm{f}$ tabel atau jika nilai sig. $F$ Change $<0,05$ maka Ho ditolak, artinya variabel bebas berpengaruh signifikan terhadap variabel terikat, 
sedangkan jika nilai sig. F Change > 0,05 maka Ho diterima, artinya variabel bebas tidak berpengaruh signifikan terhadap variabel terikat.

H7:

Ho : tidak ada pengaruh antara variabel modal, jumlah tenaga kerja, tingkat pendidikan, pengalaman, lama jam kerja, usia para pedagang pasar terhadap tingkat keberhasilan usaha.

Ha : ada pengaruh antara variabel modal, jumlah tenaga kerja, tingkat pendidikan, pengalaman, lama jam kerja, usia para pedagang pasar terhadap tingkat keberhasilan usaha.

Tabel 7

Uji Simultan

\begin{tabular}{lrrrr}
\hline $\mathrm{R}$ & $\mathrm{R}$ Square & Adjusted R Square & F Change & Sig. F Change \\
\hline, $973^{\mathrm{a}}$ &, 948 &, 940 & 120,57 &, 000 \\
\hline \hline Sumber : Data primer diolah SPSS 22 & & &
\end{tabular}

Berdasarkan perhitungan statistik SPSS diperoleh nilai Fhitung yaitu 120,57 hal ini menunjukkan adanya pengaruh positif antara modal, jumlah tenaga kerja, tingkat pendidikan, pengalaman, lama jam kerja, usia para pedagang pasar terhadap tingkat keberhasilan usaha. Hasil signifikansi sebesar 0,000 $<0,05$ Dengan demikian hipotesis yang diterima adalah $\mathrm{Ha}$ dan Ho ditolak. Ini menunjukkan adanya pengaruh yang signifikan antara modal, jumlah tenaga kerja, tingkat pendidikan, pengalaman, lama jam kerja, usia para pedagang pasar terhadap tingkat keberhasilan usaha pedagang di pasar sukaramai kecamatan bengkalis.

\section{Koefisien Determinasi (R2)}

Koefisien determinasi pada intinya mengukur seberapa jauh kemampuan model dalam menerangkan variasi variabel terikat. Nilai koefisien determinasi adalah antara nol dan satu $\left(0 \leq \mathrm{R}^{2} \geq 1\right)$. Nilai $\mathrm{R}^{2}$ yang kecil berarti kemampuan variabel bebas dalam menjelaskan variabel terikat sangat terbatas. Nilai yang mendekati satu berarti variabel bebas memberikan hampir semua informasi yang dibutuhkan untuk memprediksi variasi variabel terikat secara simultan. Berdasarkan hasil perhitungan statistik pada tabel 7 uji simultan diperoleh nilai koefisien determinasi $\left(\mathrm{R}^{2}\right)$ sebesar 0,948. Hal ini menunjukkan bahwa variabel bebas dapat menjelaskan variasi variabel terikat sebesar 94,8\% sedangkan sisanya sebesar 5,2\% dijelaskan oleh variabel lain yang tidak diteliti.

\section{KESIMPULAN DAN SARAN}

Berdasarkan hasil dan pembahasan penelitian, maka kesimpulan yang dapat dikemukakan dalam penelitian ini sebagai berikut:

1. Variabel modal berpengaruh signifikan terhadap tingkat keberhasilan usaha pedagang pasar suka ramai di kecamatan Bengkalis. Semakin tinggi modal yang digunakan maka semakin besar pula tingkat keberhasilan (laba) yang diperoleh (sebagai ukuran kuantitatif tingkat keberhasilan usaha). Variabel modal memiliki pengaruh yang paling kuat jika dibandingkan dengan variabel independen yang lain. 
2. Variabel jumlah tenaga kerja berpengaruh terhadap tingkat keberhasilan usaha pada pedagang Sukaramai kecamatan Bengkalis. Tambahan tenaga kerja memang akan meningkatkan laba usaha yang diperoleh (sebagai ukuran kuantitatif tingkat keberhasilan usaha). Namun dalam kondisi tertentu, pada awalnya penambahan jumlah tenaga kerja pada tingkat tertentu akan meningkatkan pendapatan tapi jika ditambah terus maka akan menurunkan pendapatan (tingkat laba yang diperoleh).

3. Variabel tingkat pendidikan tidak berpengaruh terhadap tingkat keberhasilan usaha dagang di pasar Sukaramai kecamatan Bengkalis. Mereka yang memiliki tingkat pendidikan lebih tinggi memiliki kemungkinan tingkat keberhasilan yang tinggi dalam usaha dagang di pasar sukaramai. Namun dalam penelitian ini antara kategori tingkat pendidikan tertentu dengan tingkat pendidikan yang lain memiliki tingkat keberhasilan yang relatif setara.

4. Variabel lama usaha (pengalaman) tidak berpengaruh terhadap tingkat keberhasilan usaha dagang di pasar Sukaramai kecamatan Bengkalis. Variabel ini memiliki pengaruh yang paling lemah dibandingkan dengan variabel independen lainnya.

5. Variabel lama jam kerja berpengaruh signifikan terhadap tingkat keberhasilan usaha dagang di pasar Sukaramai kecamatan Bengkalis. Semakin lama jam kerja maka semakin tinggi pula laba usaha yang diperoleh.

6. Variabel faktor usia tidak berpengaruh signifikan terhadap tingkat keberhasilan usaha dagang dalam meningkatkan pendapatan usaha dagang dipasar sukaramai. Artinya tidak ada perbedaan pendapatan baik pedagang tersebut lebih muda atau lebih tua.

7. Secara bersama-sama, keenam variabel independen (modal, jumlah tenaga kerja, tingkat pendidikan, pengalaman, lama jam kerja, dan usia para pedagang pasar Sukaramai kecamatan Bengkalis) berpengaruh terhadap tingkat keberhasilan usaha dagang di pasar Sukaramai Bengkalis.

Berdasarkan hasil penelitian maka sebagai saran adalah sebagai berikut:

1. Untuk meningkatkan pendapatan bagi usaha dagang, para pengusaha hendaknya mengalokasikan faktor-faktor penting berdasarkan hasil kajian, maka yang perlu ditingkatkan seperti; modal usaha, lama jam kerja dan jumlah tenaga kerja sesuai dengan kondisi keperluannya.

2. Terkait dengan faktor lama usaha (pengalaman), para pengusaha dipasar sukaramai disarankan untuk selalu tekun dalam menjalankan usahanya agar dapat mengasah kemampuan profesionalnya dalam berwiraswasta, dapat meningkatkan pengetahuan tentang selera ataupun perilaku konsumen, keterampilan berdagang makin bertambah, dan semakin banyak pula relasi bisnis maupun pelanggan yang berhasil dijaring.

3. Berkaitan dengan model yang digunakan dalam penelitian ini, maka perlu dikembangkan lagi faktor-faktor lain yang diduga mempengaruhi keberhasilan usaha dagang untuk meningkatkan pendapatan (laba usaha).

\section{DAFTAR PUSTAKA}

Amirullah dan Hardjanto, Imam. 2005. Pengantar Bisnis, Edisi Pertama. Yogyakarta: Graha Ilmu. 
Arifin, Bustanul. 2004. Formasi Strategi Makro-Mikro Ekonomi Indonesia, Edisi 1. Jakarta: Ghalia Indonesia.

Asmie, Poniwatie. 2008. Analisis Faktor-Faktor yang Mempengaruhi Tingkat Pendapatan Pedagang Pasar Tradisional di Kota Yogyakarta. Jurnal NeOBis, Volume 2 No. 2 Desember, hal. 197-210.

Dawwabah, Asyraf Muhammad. 2014. Menjadi Entrepreneur Muslim Tahan Banting. Surakarta: Al-Jadid.

Hasyim, H. 2006. Analisis Hubungan Karakteristik Petani Kopi Terhadap Pendapatan (Studi Kasus: Desa Dolok Saribu Kecamatan Paguran Tapanuli Utara). Jurnal Komunikasi, Vol.18, No.1:22-27.

Hendra, Yopi dan Riana, Deny. 2008. Spiritual Entrepreneur. Bandung: MQS Publishing.

Mc.Eachern, Wiliam A. 2001, Ekonomi Mikro Pendekatan Kontemporer, Edisi Pertama. Jakarta: PT Salemba Empat.

Primiana, Ina. 2009. Menggerakkan sektor riil UKM \& industri. Bandung: Alfabeta.

Priyanto, Sony Heru. 2009. Mengembangkan Pendidikan Kewirausahaan di Masyarakat. Jurnal PNFI, Vol.1, No.1, pp. 57-82.

Purnama, Chamdan dan Suyatno. 2010. Motivasi dan Kemampuan Usaha Dalam meningkatkan Keberhasilan Usaha Industri Kecil (Studi Pada Industri Kecil Sepatu di Jawa Timur). Jurnal Manajemen dan Kewirausahaan, pp. 177184.

Riyanto, Bambang. 2010. Dasar-Dasar Pembelanjaan Perusahaan, Ed. 4. Yogyakarta: BPFE.

Simanjuntak, P.J. 2001. Pengantar Ekonomi Sumber Daya Manusia, Edisi Kedua. Jakarta: Lembaga Penebit Fakultas Ekonomi Universitas Indonesia.

Tambunan, Tulus T.H. 2002. Usaha Kecil dan Menengah di Indonesia, Beberapa Isu Penting. Jakarta: Salemba Empat.

Undang-Undang Nomor 13 Tahun 2003 tentang Ketenagakerjaan

Undang-undang RI. No. 20 Tahun 2003 Tentang Sistem Pendidikan Nasional. Jakarta: Sinar Grafika.

Widjajanta, Bambang dan Widyaningsih, Aristanti. 2007. Mengasah Kemampuan Ekonomi, Cetakan 1. Bandung: Citra Praya. 